DOI 10.1515/LINPO-2016-0006

\title{
Józef Darski (1942-2016) and his contribution to the German linguistics and grammar
}

\author{
Janusz Taborek ${ }^{1}$ \\ Institute of German Studies, Adam Mickiewicz University in Poznań \\ e-mail: janusz.taborek@amu.edu.pl
}

\begin{abstract}
The linguist and grammarian, Józef Darski (born 30 $0^{\text {th }}$ August 1941) died on $18^{\text {th }}$ March 2016 in Poznan. This contribution presents his life and innovative and original work. His outstanding achievement was a holistic, original, generic and empirical-based model of linguistic analysis, concerning all of its levels. Based on his model, Darski proposed original ways of presenting stems and exponents, a system of word classes, regular and irregular verbs, as well as noun and adjective declension. Józef Darski was a respected and esteemed teacher and a master for many Polish Germanists as well as a successful university administrator serving as dean of his faculty for several years. His death was a loss for German studies in Poland.
\end{abstract}

Keywords: Józef Darski, German, grammar, linguistic analysis, theory of language

\section{Biography and academic profile}

\section{1. Biography}

A linguist and grammarian, Józef Paweł Darski was born on $30^{\text {th }}$ August 1941 in Łobżenica, northern Wielkopolska. He studied German philology at Adam Mickiewicz University in Poznań, where he received his all academic grades and titles, and this university became his workplace for his entire life. He graduated on $14^{\text {th }}$ May 1965 with the thesis "Historische Phonetik der Mundart von Sępólno" and achieved his doctor of humanities in German linguistics on $14^{\text {th }}$ January 1974 with the thesis "Morphonologie der Reste der ehemaligen deutschen Mundart von Sępólno Krajeńskie", both written under the supervision of Professor Ludwik Zabrocki. On 2nd April 1987 he passed his habilitation colloquium at the Faculty of Philology and received the venia legend in linguistics with his most important work, presenting his original model of linguistic analysis, "Linguistische Analysemodell. Definitionen grundlegender grammatischer Begriffe".

1 The author would like to thank to Prof. Mikhail Kotin, Prof. Beata Mikołajczyk, Prof. Ewa Żebrowska and Dr Marta Woźnicka for their valuable comments and suggestions to improve the quality of the paper. 
On $14^{\text {th }}$ December 1999 Józef Darski received the title of professor, presenting his book "Bildung der Verbformen im Standarddeutschen".

Józef Darski spent his entire academic career at the University in Poznań. After receiving his MA, he became a junior assistant (1965), assistant (1966) and senior assistant (1968) at the Chair for (West)Germanic Languages, led by Ludwik Zabrocki. From 1974, Józef Darski worked as an adjunct and after 1988 as docent at the Chair for Westgermanic Languages in the Institute of German Studies that was founded in 1969. In 1990 Józef Darski became university professor and chair of the Department of descriptive grammar of German, that was established on his initiative. The next academic positions of Józef Darski were extraordinary professor (2000), full professor (2005) and, after retiring, senior professor (from 2012 until 2016).

Józef Darski was also active in the university administration, as dean of the Faculty of Modern Languages and Literatures (2002-2008) as well as deputy dean for research at the same faculty (1988-1993 and 1996-2002).

Academic work at his host university was interrupted only by scholarships in Germany or sabbaticals. Józef Darski spent ten months in Rostock (1970-1971) and, after becoming fellow of the Alexander von Humboldt Foundation, he worked at the Institute of German Language in Mannheim (1980-1981), as well as at the Free University of Berlin (1995).

Professor Józef Darski taught at the university for almost five decades. He gave courses in German grammar and Introduction to linguistics, as well as giving many MA and $\mathrm{PhD}$ seminars in German linguistics. He was supervisor of over two hundred master theses, as well as nine doctoral theses.

Professor Józef Darski died on 18th March 2016 in Poznań leaving his wife, children and grandchildren.

\subsection{Research profile}

His research interests in the 1960s were dialectology and the remnants of German colonial varieties in Poland, in which he followed his teacher, Ludwik Zabrocki. In his diploma thesis, Józef Darski worked out the phonetics of the variety of the region of Sępólno Krajeńskie in central Poland, and in his doctoral dissertation he continued his dialectal studies, and worked on the morphology and phonology of that variety. The work was descriptive and Zabrocki's research team at this time involved, among others, German linguists like lexicographer Jan Czochralski, the computer scientist Leonard Bolc, as well as two later spiriti movens of applied linguistics in Poland, Franciszek Grucza in Warsaw and Waldemar Pfeiffer in Poznań.

After receiving his $\mathrm{PhD}$, Józef Darski worked more on didactic questions, especially in the 1970s and 1980s, and he combined his later research with practical aspects of grammar problems faced by teachers, especially those teaching German as a foreign language. Some of his solutions, presented in this paper, concern the declension of adjectives, building verb forms in German, declension of nouns as well as passive voice constructions etc. 
At the same time, Józef Darski developed a holistic, original, generic and empirically-based model of linguistic analysis, concerning all levels of language analysis. He presented an idea for a theoretical framework to the Alexander von Humboldt Foundation, which agreed with his plans and which enabled him to speak about his ideas with German linguists during his stay in Germany, e.g. Ulrich Engel, Johannes Erben und HansJörg Heringer. The model was published 1987 and submitted to the Faculty of Philology as a habilitation dissertation. The theoretical framework, presented in section 2 of this paper, was verified by his own works on German grammar, as well as by his students at the university. The modified and extended second edition of the Darski model was published in 2004 in Poznań.

All the three mentioned research fields of Józef Darski, e.g. dialectology, language teaching and linguistic analysis, involved and interacted with the fourth, and main field of Józef Darski's research interest, namely German grammar.

\section{The linguistic model of analysis}

\subsection{Introduction and methodology}

The aim of Józef Darski's linguistic analysis model, presented in Darski (1987) and Darski (2004), is "the definition of fundamental grammatical concepts" (Darski 1987: 2) and the description of a language, as well as further comparisons of languages that belong to different language families or types, because that analysis is based on "general principles of human language" (Darski 2004: 11). For Darski the common properties of all languages are the following:

- the plane of expression utilizes human speech apparatus;

- it is impossible to speak continuously without breathing in;

- it is possible to form questions in every language;

- communication between people is achieved with utterances.

Linguistic analysis, as perceived by Józef Darski, is determined by the four aforementioned general properties and is influenced by two structuralist linguists, Louis Hjelmslev and Zelig Harris, cf. Kotin (forth.). Following Hjelmslev's Glossematics, Darski distinguishes between the plane of expression (Ausdrucksebene) and the content plane (Inhaltsebene) as well as between syntagmatic and paradigmatic relations, with reference to Hjlemslev and, of course, to Ferdinand de Saussure. Darski (2004: 14) refers implicitly to Hjelmslev and his first principle of the theory, the so-called empirical principle, according to which

\footnotetext{
"[t]he description shall be free of contradiction (self-consistent), exhaustive, and as simple as possible. The requirement of freedom from contradiction takes precedence over the requirement of exhaustive description. The requirement of exhaustive description takes precedence over the requirement of simplicity." (Hjelmslev 1963: 11)
}

In line with Hjelmslev's theory of language, Darski (2004: 21) begins his analysis of the plane of expression with the definition of the term text, which is seen as 
“das Ergebnis des Vorkommens von Sprache in manifestierter Erscheinungsform, also das alles, was der jeweilige Sprecher seinem Hörer (seinen Hörern) in materieller Form (primär Schallform) in einer Interaktion mitteilt”.

Text is segmented into text sequences of a single speaker (Textsequenz eines Sprechers) along with changes of speaker. These are then segmented into utterances (Äußerungen) according to the occurrence of pauses produced by a speaker. Utterances are segmented into utterance segments (Äußerungsabschnitte) in line with the so-called minimal pauses and progredient (level) intonation. And utterance segments are divided into speech syllables (Sprachsilben), cf. Darski (2004: 31-33) that are composed of sounds (Laute), which are gained with the criterion of stretching syllables and by deleting identified sounds from complex syllables. The next step in Darski's analysis are abstract units, which are identified firstly for a single native speaker of the language. Idiolectally phonoids are sounds that have the same manner of articulation. Idiolectally phones are sounds that have the same "aural impression of the hearer", cf. Darski (2004: 39-40). Idiolectally phonemes are sounds that guarantee the identical meaning of a text sequence. The third abstract units are then generalized to phonoid, phone and phoneme of a single language. This way of identifying and classifying of all units of the plane of expression also follows the main principle of Hjelmslev's theory, whose aim is to discover the smallest units, while the consequent top down analysis of language, in the form of a pyramid, follows Zellig Harris.

The content plane is also subjected to a top down analysis by Darski (2004, 51-62), starting with the text as the greatest linguistic unit, whereby according to Coseriu (1981: 47) Darski distinguishes between designation (Bezeichnung), which means the reference to extra-linguistic reality, meaning (Bedeutung), which means designation in one specific language, and sense (Sinn), which means the interpretation of meaning. For the classification of parts of speech and syntactic functions, which is the main aim of morphosyntax, Darski proposes the sub-classification of utterances and word forms. Utterances are divided into minimal utterances (Minimaläußerung), which are understandable only on the basis of preceding utterance(s), because they omit parts which can be deduced from the preceding utterance(s) by a native user of the language, and the remaining utterances are complete utterances (vollständige Minimaläußerungen). Using interrogative testing as a general method following the general principles of his analysis, Darski (2004: 56-62) defines the potential minimal utterance (potenzielle Minimaläußerung). It is part of a complete utterance, can be asked and can be used as a minimal utterance, cf. Darski (2004: 59-60). Minimal utterances are divided into complex minimal utterances (komplexe Minimaläußerung) and simple minimal utterances (einfache Minimaläußerung), which are the smallest units of language defined using interrogative testing.

The next fundamental question is the definition of the concept of the word. According to Igor Mel'čuk's postulate that it is not possible to use the traditional concept of the word in linguistic theory, Darski avoids the term word and uses the term word form (Wortform). A word form is identified by the use of the concept of simple minimal utterances and by the use of further operation tests - insertion, permutation and elision. Using these tests shows affinities with the operational grammar of Zellig Harris as well 
as the Swiss linguist and grammarian Hans Glinz. Therefore, Darski distinguishes between (i) primary word forms (primäre Wortformen), which are defined as a simple minimal utterance that does not allow another minimal utterance to be inserted into it such that the new complex utterance would be accepted by native speakers, (ii) secondary word forms (sekundäre Wortformen), which allow the insertion of simple/complex minimal utterances where the new utterance is accepted by native speakers, and (iii) tertiary word forms (tertiäre Wortformen), which cannot be asked and whose definition is more complex, cf. Darski (2004: 92-93).

There are some consequences for the understanding of the word form by Darski. According to the definitions of word forms, the following combination of two traditional words are treated as a single word form: (i) prepositions together with a definite or indefinite article, e.g. $z u$ der and in dem, which are traditionally two words, as well as their contamination zur and im, which are traditionally treated as a single word; (ii) the particle $z u$ with infinitives is, according to Darski, part of the verb, and therefore $z u$ kaufen 'to buy' is a single word form, even if it is used in a verb with a prefix, e.g. einzukaufen, which consists, according to Darski, of two word forms - ein and zukaufen, but which is traditionally one orthographic word; (iii) prepositional phrases in light verb constructions e.g. zur Verfügung (stehen) 'to be at somebody's disposal' and more complex prepositional phrases in idioms, e.g. auf keinen grünen Zweig (kommen) 'to not be getting ahead', are only single word forms, because it is impossible to insert a minimal utterance into the prepositional phrase without changing the meaning of the idiom. That spelling for linguistic theory is not significant or informative is confirmed by examples like nach Hause vs. nachhause 'home', which are, for Darski, in both cases a single word-form.

The concept of utterances, especially of the construct of minimal utterance, and the concept of primary, secondary and tertiary word forms are key concepts in Józef Darski's analysis model, and they are applied in his classification of parts of speech, as well as syntactic functions (parts of sentence). The third key concept in Darski's model is the concept of stem and exponent, which will be referred to in section 3.1, because it refers to inflection, which is a morphological property.

\subsection{Terminology}

Józef Darski points out that terms are to be used according to how they are defined in the concrete theory or model. Therefore, if the traditional terms, e.g. text, noun, adjective or particle, are used in Darski's analysis model, they are defined in the model and thus they are used only in this sense, not in the traditional or other one. The author also uses new terms where necessary, and the linguistic entity has no equivalent and no correlation to existing entities. He proposes his own terms which are specific for his model e.g. potential minimal utterance or finitum modifier - see section 3.2 below.

On the other hand, for parts of speech and syntactic functions, Darski uses only numbers, e.g. Wortklasse 1, with labels called by him Merkhilfen, e.g. noun, verb or subject and object - but they are only labels and can be understood more broadly than 
in traditional grammar. In his analysis model, Darski uses numbers, but in his grammar addressed to scholars, he uses the labels in brackets to aid usability, e.g. Darski (2010).

\section{Morphology}

\subsection{Stem and exponent}

Józef Darski proposes in his analysis model an original and innovative solution to the question of the morpheme, cf. Kotin (forth.) using the terms stem (Stamm) and exponent. Darski primarily uses the phonetic realization and then the orthographic one, which he explains by the use of orthography in schools. Stems for Darski (2004: 133) are,

"[d]ie sprachlichen Mittel bzw. deren neutrale Repräsentationen, die sich in allen Wortformen verschiedener Wortarten wiederholen und immer dieselbe Bezeichnung aufweisen und/oder sich phonomorphologisch identifizieren lassen".

Stems are separated into simple inflection stems (einfacher Flexionsstamm), e.g. /ma:1/ and broad inflection stems (erweitereter Flexionsstamm), e.g. /bəma:1/ or /ma:lənD/, which consist of simple inflection stems, e.g. /ma:1/ above, and affixes - prefixes and suffixes. Inflection stems usually contain singular inflection stems and plural inflection stems. The difference between an inflection stem and a singular inflection stem is called a singular marker, and the difference between an inflection stem and a plural inflection stem is called a plural marker. Plural markers include not only traditional endings, e.g. $<\mathrm{e}>$ or $<\mathrm{er}>$, but also all the changes in a stem, e.g. $a>\ddot{a}$ in German, as in the example Haus 'house' - Häus $\underline{e r}$ 'houses'. The linguistic means which are used to express syntactic and morphological functions are called exponents. Darski specifies them into a syntactic singular exponent and syntactic plural exponents. Let us exemplify Darski's terms with the declination of the noun Kind 'child' in German.

\begin{tabular}{|c|c|c|c|c|}
\hline \multirow[t]{2}{*}{ Case } & \multicolumn{2}{|c|}{ Singular } & \multicolumn{2}{|c|}{ Plural } \\
\hline & orthographic & phonetic & orthographic & phonetic \\
\hline Nom & Kind & /kınt/ & Kinder & /kınde/ \\
\hline Gen & Kindes & /kındəs/ & Kinder & /k1nde/ \\
\hline Dat & Kind & /kınt/ & Kindern & /kınden/ \\
\hline Acc & Kind & /kınt/ & Kinder & /kınde/ \\
\hline
\end{tabular}

The change of $/ \mathrm{t} /$ to $/ \mathrm{d} / \mathrm{is}$ not overt in the orthographic form, and this change is marked by Darski with a majuscule as $/ \mathrm{k} 1 \mathrm{nD} /$, which stands for the regular change of /d/ to $/ \mathrm{t} /$, regular, that is, according to Darski at least in two forms. According to the definitions, $/ \mathrm{knD} /$ is an inflection stem and a singular inflection stem as well, /k1nd/ is a plural inflection stem, $/ \mathfrak{e} /$ is a plural marker. /os/ is syntactic singular exponent (casus: genitive) and $/ \mathrm{n} /$ is a syntactic plural exponent (casus: dative). 
Regarding verbs, Darski (2004: 125-132) distinguishes a present stem and a past stem, both in singular and plural, and there are singular and plural syntactic exponents as well as a conjunctive exponent /a/ in German.

To conclude, we can say, that Darski's solution, of using, instead of the morpheme, the precisely defined terms of stem, exponent and marker allow this to be viewed as a universal idea, cf. Kotin (forth: 3), and the concept can be used for the description and comparison of inflective, agglutinative as well as isolating languages, cf. Kotin (forth.).

\subsection{Word class}

Word forms are divided by Darski (2004: 139-190) into 18 word classes, called, in his latest publications, parts of speech, which are result of the precision and rigor of the model. Whereas the traditional semantic classification is based on the meaningful vs. meaningless dichotomy, and the traditional morphological classification is based on the inflective vs. non-inflective dichotomy, Darski's approach is found on the role or the function of the word form in the text and it is based on the dichotomy: can the word form be asked or not? The first word class are question words (Fragewörter), e.i. word forms that always cross the borders of the sequence of one speaker ${ }^{2}$ The second word class, influenced by Karl Bühler's theory, are reference words (Verweiswörter), that can cross the borders of the sequence of one speaker ${ }^{3}$. Both first classes are used in defining the rest of the word classes, which are: utterance equivalent, finitum, potential finitum, finitum modifier, genuine reflexive pronoun, formal word, modal word, particle, deixis, modal adverb, noun, function word, adjective, present participle, coordinating conjunction, and subordinating conjunction.

Of course, it is possible to sub-classify some of the classes, which Darski did, e.g. with the word class potential finitum divided into the subclasses infinitive and participle, and with the word class function word, divided into article words (determinators) and prepositions. On the other hand, it is possible to join classes into a hyper-class, e.g. finitum, potential finitum and present participle are forms of verbs. Some of the word classes are new concepts, or just are for the first time treated as a word class. The word class finitum modifier that is specific to Darski's classification contains entities that cannot be asked - non-verbal parts of particle verbs, e.g. an in the verb annehmen 'accept', the noun Rad in the phrase Rad fahren 'cycle', the verb stehen in combination with haben, e.g. Er hat sein Auto in the Garage stehen. 'His car stands in the garage', a prepositional or noun phrase in so-called light verb constructions or idioms, e.g. Das kommt nicht in Frage. 'That's out of question', or the verb in the so-called AcI-construction, e.g. Ich höre sie Klavier spielen 'I am listening to her playing piano'. This word class shows that the word classes, as well as the concept of word forms, are independent and do not rely on spelling. (i) The verb particle an can be written together or separately (Ich nehme es an. vs. Dass ich es annehme...); (ii) Rad in Rad fahren had to be written to-

\footnotetext{
2 Cf. Biernat-Sówka (2010).

3 Cf. Darski (1991), Taborek (2004).
} 
gether up to 1996, up to the reform of German spelling. (iii) The prepositional phrase in Frage is also written as infrage. For Darski's word class system, in Frage is always a single form.

What are the consequences and advantages of Darski's approach to word classes? (i) The classification is based on Darski's concept of the word form and not on the actual word, despite its definition based on meaning, or spelling; (ii) The classification refrains from the morphological criterion that can be in fact used if one wants to sub-classify any word class; (iii) According to the previous point, the classification is not restricted to inflective languages. Darski distinguished 18 word classes, which is more than the traditional classification, with usually nine to ten word classes, but on the other hand there are less classes than in the Handbook of German parts of speech - 24 word classes, cf. Hoffmann (2007) - and in the so-called tag sets in computer linguistics used for formal machine analysis, cf. Rapp (2008: 349).

\subsection{Regular and irregular verbs}

In his monograph about the formation of verb forms in German, Darski (1999: 91) proposes a simple solution to the differentiation between regular and irregular verbs with regard to the building of base forms for present, past and participles as well as conjugations. Usually, German grammarians distinguish three classes of verbs - weak, strong (both according to Grimm) and mixed verbs, even though they can also be subsumed under "regular" and "irregular" verbs, cf. Helbig/Buscha (2005: 30). This division results from diachronic analysis, and for students of German without a basic knowledge of the history of German grammar, the difference between strong and mixed verbs has no relevance. On the other hand, in English grammar there are only regular and irregular verbs.

According to that, regular verbs for Darski are those verbs that (i) have a syntactic exponent $\langle\mathrm{t}\rangle$ in the third person present indicative, (ii) are built using the suffix $<\mathrm{te}>$ in past and using $\langle\mathrm{t}\rangle$ in the past participle, and (iii) have a consistent stem in all word forms in paradigms of conjugation, cf. Darski (2010: 235). Any verb that does not fulfil one of these requirements is an irregular verb. This idea is not new and refers to Adelung (1801: 259-267), who, using the criteria mentioned by Darski under (ii) and (iii), also divides verbs in regular (regulär) and irregular (irregulär or abweichend) ${ }^{4}$.

\subsection{Inflection of nouns}

The declination of nouns that can be presented in different numbers of inflection paradigms, e.g. Helbig/Buscha (2005: 211-220), is described by Darski within five rules, in which the author separates singular from plural to avoid the traditional point of view, and to avoid the traditional distinction of strong, weak and missed declension. According

${ }^{4}$ Darski (2015: 513) refers to Adelung and his classification of verbs used in a handbook of German for schools. Also Darski (2010: 239) simplified the rules of distinguishing regular and irregular verbs for students. 
to them, and using the well-defined terms of stem, number marker and syntactic exponent, Darski (2010: 272-274) proposed following two rules (i) - (ii) for the singular, and three rules (iii) - (v) for the plural:

(i) Only nouns ending with $<\mathrm{l}>,<\mathrm{e}>$ and $<\mathrm{r}>$ in the nominative plural, have a syntactic exponent $<\mathrm{n}>$ in the dative plural, e.g. Bäume 'trees' - Bäumen;

(ii) Nouns ending with letters other than $<\mathrm{l}>,<\mathrm{e}>,<\mathrm{r}>$ have no syntactic exponent in the plural, e.g. Namen 'names' - Namen;

(iii) Nouns that have syntactic exponents $<(e) n>$ or $<(e) n s>$ in the genitive singular, have a syntactic exponent $<(\mathrm{e}) \mathrm{n}>$ in the dative and accusative singular, e.g. Herrn Herrn, Studenten - Studenten, Namens - Namen;

(iv) Nouns with syntactic exponents $<\mathrm{s}>$, $<$ es $>$ or $<$ ses $>$ in the genitive singular, have no syntactic exponents in other cases, e.g. Peters - Peter, Kindes - Kind, Erignisses Ereignis;

(v) Nouns with no syntactic exponents in the genitive singular, have no syntactic exponents in other cases, e.g. Frau - Frau.

These five, simple rules can be used when three forms of noun are established, namely nominative singular, genitive singular and nominative plural, which are usually given in monolingual as well as bilingual dictionaries.

\subsection{Passive voice, passive utterances and non-agentivity}

Depending on the semantic role of the subject, Darski (2010: 374-385) divides utterances into active utterances, where the subject has an agentive or pseudoagentive role, and passive utterances. In passive utterances, (i) the subject expresses the patient or (ii) the subject is formal subject, e.g. es in German, or (iii) there is no subject, whereas the verbum finitum is used in the third person singular. According to the aforementioned definition of passive utterances, there are passive utterances with a subject being the accusative object in the active utterance, and passive utterances without subject ${ }^{5}$.

The conclusion for grammar books is that there are different types of passive utterances but only the combination of werden + past participle is treated in Darski (2012: 430) as the passive voice ${ }^{6}$. As a result, the types of infinitive verb forms in German contain active and passive infinitives for present and past ${ }^{7}$.

According to the model and linguistic analysis, the construction sein 'be' + past participle that are called Zustandspassiv 'stative passive voice' or sein-Passiv and treated in German grammars since the 1950s as the passive voice, are not passive for Darski. The

\footnotetext{
5 The terms utterance with subject and utterance without subject are used to avoid the traditional terms used e.g. in Helbig/Buscha (2005: 150-151), i.e. persönliches vs. unpersönliches Passiv, although Helbig/Buscha (2005: 150) use the term „subjektlose Passivsätze”, affin to Darski's „Passiväußerungen ohne Subjekt” (Darski 2010: 378).

${ }^{6}$ Although in earlier works, e.g. Darski (1994) nonagentive passive utterances are also partially seen as passive. The presentation of the passive in Darski's grammar is as stated in Darski (2012) and later editions.

7 In older works by Darski (1999: 198) there is a distinction between the infinitive process passive, e.g. geliebt werden, and infinitive stative passive, e.g. geliebt sein.
} 
main reason is that the participle in these constructions can be asked and the interrogative test is possible, cf. Darski (2015: 514), so we have a construction (copula) verb sein + past participle, so called Verbaladjektiv, cf. Abraham (1995: 124), and the other reason is that not all constructions sein + participle perfect can be derived from passive constructions with werden. ${ }^{8}$

\subsection{Adjective declension in German}

Adjectives, as a word class, has different range from its traditional understanding, cf. Darski (2004: 178). The range of adjectives is broader, because according to their definition, adjectival numerals as well as verb participles used adjectivally with nouns are adjectives. In other ways, though, the range of Darski's adjectives is narrower, because so-called adjective-adverbs or adjectives used in adverbial function as well as adjectives used post-nominal, e.g. Whisky pur, are not adjectives.

But Darski doesn't only define adjectives precisely. In his early paper on German grammar, which is referred by e.g. Zifonun et al. (1997), Eroms (2000), "Die Adjektivdeklination im Deutschen", Darski (1979) avoided the traditional view of three paradigms in adjectival inflection, i.e. strong, weak and mixed, depending on the article used before, and suggested two rules on the basis of syntactic exponents.

Firstly, if the categories of case and gender in the singular, as well as case in the plural, are expressed in the syntagmatic nominal, the group contains a determiner/personal pronoun ${ }^{9}+$ adjective(s) + noun, then the syntactic exponents of adjectives are: $<\mathrm{e}>$ in the nominative singular of all genders, and in the accusative plural of feminine/neuter, and $<$ en $>$ in other cases of singular as well as plural. These syntactic exponents are called non-determining exponents.

Secondly, if the categories of case and/or gender in the singular, as well as case in the plural are not expressed in the same syntagmatic nominal, the group contains a determiner/personal pronoun + adjective $(s)+$ noun, then the syntactic exponents of adjectives are inferred from the syntactic exponents of the article dieser, diese, dieses 'this' in the singular and diese 'these' in the plural, and in the case of the nominal group. These syntactic exponents are called determining exponents.

The theoretical discussion in Darski (1979) is followed by a didactic preparation of adjective declension where both rules are exemplified, cf. Darski (1984), and an algorithm for finding the required syntactic exponent is given. The rules are part of German grammar (Darski 2010: 322).

${ }^{8}$ Zustandspassiv is also not accepted in German grammar e.g. by Griesbach (1986: 106), Leiss (1992: 173), Abraham (1995: 124), Rapp (1996: 231) as well as by Maienborn (2007).

9 The determinator, cf. Darski $(1979 ; 1984)$ is later, e.g. Darski (2010) replaced it with a more specific and detailed expression: article or personal deixis $i c h$ 'I', $d u$ 'you', wir 'we', ihr 'you' or reference words $i h m$ 'him' and $i h r$ 'her'. 


\section{Syntax}

\subsection{Terms Satz and Satzglied}

Darski does not use either the traditional term Satz 'sentence' or the traditional term Satzglied 'part of the sentence'. The main syntactic unit in Darski's model is the utterance (Äußerung) ${ }^{10}$, that is according to Darski (2004: 28) a "Segment der Textsequenz eines Sprechers, die bei ruhiger ununterbrochener Rede durch Ausklingen der Stimmführung gewonnen werden, ohne dass dadurch das Verständnis der Textsequenz eines Sprechers beeinträchtigt wird". This means that the utterance is defined, despite its inner structure, and is understood more broadly than Satz 'sentence' in traditional grammar.

If an utterance is understandable only on the basis of the preceding utterance(s), as in dialogues, it is called a minimal utterance, otherwise the utterance is a complete utterance. Utterances are also divided according to the number of verba finita into: (i) elliptic utterance, that have no verbum finitum, (ii) simple utterances and (iii) complex utterances. The definitions of simple and complex utterance are specific using the sub-classes of paradigmatic utterances, cf. Darski (2004: 171-174).

It is obvious that there are linguistic units on the level above word forms and under utterances, namely utterance constituents (Äußerungsglieder), cf. Darski (2004: 195). Firstly, Darski (2004: 195) assumes that all word forms have a function in an utterance, and therefore also traditional word classes like conjunctions and particles are utterance constituents. Secondly, an utterance - especially a minimal utterance - has to be complete before one begins to determine its syntactic functions i.e. utterance constituents. Thirdly, there are first degree utterance constituents, which are all linguistic units that are present after substitution e.g. with reference words. Fourthly, the only test used for the identification of utterance constituents represented by primary, secondary and tertiary word forms is substitution (Ersatzprobe).

The results of the aforementioned assumptions are 31 utterance constituents ${ }^{11}$ and the huge number of constituents - if one compares their number with the traditional constituents, e. g. predicate, subject, object, adverbial and attribute - results from consistently applied criteria. It is possible to combine specific utterance constituents into groups, e.g. constituents 20 to 31 - Wie-Glied, Wo-Glied etc - are traditional adverbials (cf. Helbig 1989: 59; Darski 2004: 214) and can also be combined into groups of local, temporal, modal and causal adverbials, cf. Taborek (2004: 103), but Darski avoided any mixed criteria. Every utterance constituent has a proposed label, e.g. Wie-Glied, Wo-Glied, that is on the one hand easy to remember, due to the use of object language (wie, wo, etc), but, on the other hand, it is also possible to use semantically motivated labels of

10 See also the Polish term wypowiedzenie 'utterance' used in Polish syntax for the first time by Klemensiewicz (1933) and then e.g. by Saloni/Świdziński (2004: 41)

11 They have numbers and German labels: Schaltglied, Leitglied, potenzielles Leitglied, Leitmodifikator, Modalglied, Partikelglied, Konjunktionalglied, Formwortglied, formales Akkusativglied, formales Dativglied, fromales Präpositionalglied, Subjekt, Was-Glied, Akkusativobjekt, Dativobjekt, freies Dativglied, Gentivobjekt, Präpositionalobjekt, freies Präpositionalglied, Wie-Glied, Wo-Glied, Wohin-Glied, Woher-Glied, Wann-Glied, Bis wann-Glied, Seit wannGlied, Wie oft-Glied, Wie lange-Glied, Wie weit-Glied, Warum-Glied. 
Latin origin, e.g. modal (Wie-Glied), locative (Wo-Glied), ablative (Woher-Glied), allative (Wohin-Glied) etc, as proposed in Taborek (2004: 103) or Poźlewicz, Duch-Adamczyk \& Schatte (2013: 31-32, 40-41).

\subsection{Word order}

The word order in German utterances, which is influenced by its syntactic structure, information content (e.g. topic - comment) and the intention of the speaker, was the most commonly chosen research topic based on Darski's analysis model because of the precision of the utterance constituents. ${ }^{12}$ According to the theoretical premises and the consistency in the identification of utterance constituents, there are interesting results in the realization of the so-called Vorfeld, the linear position before finitum. Darski (2010: 394397) realizes that the Vorfeld is more often represented by two constituents than in traditional analysis (cf. Mikołajczyk (1999)), which is caused, among other things, by treating conjunctions as a constituent, opposite to other German grammars, e.g. Helbig/Buscha (2005: 444).

The German grammar of Darski contains a lot of detailed rules for locating constituents in the topology of the German sentence. There are also detailed descriptions of the order of constituents in the centre field, called the Mittelfeld depending on the aforementioned factors, e.g. information, intention, morphological form and the presence or absence of other constituents such as a subject. The rules are based on several case studies made by Darski's students and collaborators ${ }^{13}$.

\section{Contrastive, diachronic and dialectal studies}

Although the linguistic analysis model based on Hjelmslev's principles is synchronic and mostly exemplified using German, it is possible to apply the model to contrastive studies, diachronic studies and also in areal linguistic studies.

In contrastive studies, the model was applied in Darski's German grammar published in Polish, cf. Darski (2012), that contains, as mentioned in the subtitle of the book, "contrastive remarks" and is addressed to Polish students. Other contrastive studies German-Polish using the linguistic analysis model in question, are concerned with reference words $^{14}$, question words ${ }^{15}$, article and demonstratives ${ }^{16}$ as well as word order ${ }^{17}$.

Because the model and the approach are very general and universal, it is possible to apply it to diachronic studies, cf. Kotin (2008: 171). Kotin uses the concept of reference

12 cf. Mikołajczyk (1997; 1998; 1999; 2000a; 2000b), Radojewska (2008), Żebrowska (2005); Contrastive studies on word order based on Darski's model are Piosik (2014a; 2014b).

13 cf. Mikołajczyk (1996; 1997; 1998; 1999; 2000), Żebrowska (2002), Radojewska (2008).

14 cf. Taborek (2002; 2004).

15 cf. Biernat-Sówka (2012).

16 cf. Tęcza (2008).

17 cf. Piosik (2014a; 2014b), who analysed word order in spoken German and Polish. 
stems, with the extra distinction between constant units and variable units inside the stem, and syntactic exponents for the analysis of verbs in the diachronic perspective, as illustrated by the verb geben 'give' and its stem evolved from Indo-Germanic, via Gothic to all later stages of German, i.e. Old High German, Middle High German and New High German, cf. Kotin (2008), Radojewska (2013) and Woźnicka (2014b), as well as in diachronic and typological study on Gothic, cf. Kotin (2012). Further historical studies based on Darski's model include systematic and diachronic studies of syntactic exponents in verbal inflection as well as in nominal inflection ${ }^{18}$.

The linguistic analysis model is also used in language varieties and German dialects that were Darski's first linguistic interests. Żebrowska (2002) analyzed the middle German dialect in terms of morphology, e.g. stems and syntactic exponents in verbal and nominal declension. The word order of High Prussian in former East Prussia was analyzed using Darski's model in Żebrowska (2004) ${ }^{19}$.

\section{Conclusions}

Józef Darski is the author of an original, holistic, general linguistic analysis model that, on the one hand, "goes its own ways and makes one think"20 (Helbig 1989: 59) and can be used for a "homogenous description of different types of languages and their productive contrastive comparison" (Grucza 2008: 27). The model was, and still is used in studies of German grammar, contrastive linguistics, historical linguistics and areal linguistics as well. The analysis model, the main achievement of Józef Darski, placed him in "the circle of modern theoretical linguists", cf. Grucza (2008: 28) ${ }^{21}$.

The German grammar (Darski 2010) was a result and the culmination of his more than 40 years of study into specific grammar questions, usually including (i) a logical definition of the items according to the rationales of Louis Hjelmslev's Glossematics and (ii) simple rules of declension appropriate for learners of German. His grammar is seen as "an original work that makes one's think about traditional views and which deserves further critical discussion" ${ }^{22}$ wrote Steinke (2015) in his review of the Deutsche Grammatik in question.

Other studies and interests, e.g. the aforementioned early dialectal studies in the 1960 s and 1970s, and pedagogical applications of his theoretical works complete the spectrum of Józef Darski's achievements. As a university teacher, supervisor and master in the

${ }^{18}$ For verbal inflection cf. Radojewska (2013), Woźnicka (2014a; 2014b; 2015); for nominal inflection cf. Borkowska (2004)

19 There are further studies on dialects within Darski's linguistic analysis model, cf. Dolatowski (2016).

20 „Die Arbeit geht eigene Wege und regt in vielen Punkten zum weiteren Nachdenken an.” (Helbig 1989: 59)

21 „Das vom Jubilar [Józef Darski - J.T.] zuletzt dargelegte Model ist bereits so allgemein gefasst, dass es als Basis nicht nur für eine hochgradig homogene Beschreibung von Sprachen verschiedenen Typs, sondern auch für deren fruchtbare kontrastive Gegenüberstellung dienen könnte. Durch diese Arbeit ist der Jubilar in den Kreis der modernen Sprachtheoretiker aufgestiegen." (Grucza 2008: 27-28).

22 “Auf jeden Fall ist Darskis Grammatik eine originelle Arbeit, die zum Überdenken mancher herkömmlicher Positionen in der Germanistik anregt und eine weitere kritische Auseinandersetzung verdient." (Steinke 2015) 
traditional sense, Józef Darski was representative of Wilhelm von Humboldt's educational ideal, with the central idea of the unity of research and teaching at universities. Last, but not least, he was, as Grucza puts it (2008: 23), a "remarkably modest, sincere man with unalterable moral axioms" 23 .

\section{Bibliography}

Abraham, Werner. 1995. Deutsche Syntax im Sprachenvergleich: Grundlegung einer typologischen Syntax des Deutschen. Tübingen: Stauffenburg.

Adelung, Johann C. 1801. Deutsche Sprachlehre für Schulen. Berlin: Vossische Buchhandlung.

Biernat-Sówka, Joanna. 2010. Fragewörter im Deutschen. Ein Beitrag zu ihrer Definition und Klassifikation. Kwartalnik Neofilologiczny 57(3). 297-317.

Borkowska, Iwona. 2004. Die syntaktischen Exponenten und Numerusmarker des Substantivs vom Gotischen bis zum Gegenwartsdeutschen. (Unpublished doctoral dissertation) Adam Mickiewicz University in Poznań, Poland.

Coseriu, Eugenio. 1981. Textlinguistik. Eine Einführung. Tübingen: Narr.

Darski, Józef. 1979. Die Adjektivdeklination im Deutschen. Sprachwissenschaft 4(2). 190-205.

Darski, Józef. 1984. Die pädagogische Aufbereitung der adjektivdeklination im Deutschen. Studia Germanica Posnaniensia 13. 31-44.

Darski, Józef. 1987. Linguistisches Analysemodell. Definitionen grundlegender grammatischer Begriffe. Poznań: Wydawnictwo UAM.

Darski, Józef. 1991. Verweiswörter im Deutschen. In: Klein, Eberhard \& Pouradier Duteil, Francoise \& Wagner, Karl-Heinz (eds.): Betriebslinguistik und Linguistikbetrieb. 201-206, Tübingen: Niemeyer.

Darski, Józef. 1994. Zur Bildung des Passivs im Deutschen, In D. Halwachs \& I. Stütz (eds.): Sprache Sprechen - Handeln. Akten des 28. Linguistischen Kolloquiums, Graz 1993, 45-51, Tübingen: Niemeyer.

Darski, Józef. 1999. Bildung der Verbformen im Standarddeutschen. Tübingen: Niemeyer.

Darski, Józef. 2004. Linguistisches Analysemodell. Definitionen grundlegender grammatischer Begriffe. Poznań: Wydawnictwo UAM.

Darski, Józef. 2009. Das Genus Verbi im Deutschen. Kwartalnik Neofilologiczny 56, 1/2009, 3-23.

Darski, Józef. 2010. Deutsche Grammatik. Ein völlig neuer Ansatz. Frankfurt a.M. et al.: Peter Lang Verlag

Darski, Józef. 2012. Gramatyka niemiecka z uwagami konfrontatywnymi. Poznań: Wydawnictwo UAM.

Darski, Józef. 2015. Deutsche Grammatik. Ein völlig neuer Ansatz. 2., aktualisierte und erweiterte Auflage. Neubearbeitung für Deutsch-als-Fremdsprache-Unterricht. Frankfurt a.M. et al.: Peter Lang Verlag

Eroms, Hans-Werner. 2000. Syntax der deutschen Sprache. Berlin et al.: de Gruyter.

Griesbach, Heinz. 1986. Neue deutsche Grammatik. Berlin et al.: Langenscheidt.

Dolatowski, Marek. 2016. Alznerisches Verb aus synchroner Sicht. In Weigt, Zenon (ed.): Die deutsche Sprache in vielfältigen Forschungsparadigmen. Beiträge polonischer Doktoranden anlässlich der 9. Linguistischen Tagung-Łódź, 09.05.2015, 27-41. Łódź: Wydawnictwo UŁ.

Griesbach, Heinz. 1986. Neue deutsche Grammatik. Berlin et al.: Langenscheidt.

Grucza, Franciszek. 2008. Zur wissenschaftlichen Wirkung von Professor Józef Darski. In Mikołajczyk, Beata \& Kotin, Michail, Terra grammatica. Ideen - Methoden - Modellen, 23-31.

Helbig, Gerhard \& Buscha, Joachim. 2005. Deutsche Grammatik. Ein Handbuch für den Ausländerunterrricht. Berlin et al.: Langenscheidt.

Helbig, Gerhard. 1989. [Rec.] Józef Darski: Linguistisches Analysemodell. Definitionen grundlegender grammatischer Begriffe. Deutsch als Fremdsprache 26(1). 57-59.

Hjelmslev, Louis. 1963. Prolegomena to a Theory of Language. Madison: The University of Wisconsin Press.

Hoffmann, Ludger (ed.). 2007. Handbuch der deutschen Wortarten. Berlin/New York: Walter de Gruyter.

Klemensiewicz, Zenon. 1937. Składnia opisowa wspótczesnej polszczyzny kulturalnej. Kraków: PAU.

23 „Professor Darski war und ist ein außerodentlich bescheidener, ehrlicher Mensch mit unverrückbaren Moralvorstellungen" (Grucza 2008: 23) 
Kotin, Michail (forth.). Ein linguistisches Analysemodell zwischen Tradition und Innovation. Der Beitrag von Józef Darski (1941-2010) zur nationalen und internationalen germanistischen Grammatikforschung. (Talk given during the Congress of the Polish Association of Germanists (SGP) on 20.05.2016)

Kotin, Michail. 2008. Das "linguistische Analysemodell” von Józef Darski im sprachhistorischen bzw. Spractypologischen Diskurs. In: Mikołajczyk, Beata \& Kotin, Michail, Terra grammatica. Ideen - Methoden - Modellen, 23-31.

Kotin, Michail. 2012. Gotisch. Im (diachronischen und typologischen) Vergleich. Heidelberg: Winter.

Kotin, Michail. 2013. Einige Besonderheiten der Anwendung des Linguistischen Analysemodells von Józef P. Darski bei der Beschreibung der morphologischen Systeme älterer Sprachstufen der Indogermania. Studia Germanica Posnaniensia 33, 43-57.

Leiss, Elisabeth. 1992. Die Verbalkategorien des Deutschen. Ein Beitrag zur sprachlichen Kategorisierung. Belin \& New York: de Gruyter

Maienborn, Claudia. 2007. Das Zustandspassiv. Zeitschrift für Germanistische Linguistik 35, 83-115

Mikołajczyk, Beata \& Kotin, Michail. 2008. Terra grammatica. Ideen - Methoden - Modellen. Festschrift für Józef Darski zum 65. Geburtstag. Frankfurt a.M. et all.: Peter Lang Verlag

Mikołajczyk, Beata. 1997. Noch einmal über die Klammer. Studia Germanica Posnaniensia 23, $115-130$.

Mikołajczyk, Beata. 1998. Zur Nachfeldbesetzung im Deutschen. Glottodidactica 25. 63-72.

Mikołajczyk, Beata. 1999. Einige Bemerkungen zum Vorfeld im Deutschen. Acta Neophilogica 1. 62-72.

Mikołajczyk, Beata. 2000. Eine kurze Skizze der Wortstellungsforschung. Acta Neophilologica 2. 33-66.

Piosik, Michał. 2014a. Das unbesetzte Linke Feld im Deutschen und im Polnischen. Eine konstrative Analyse der gesprochenen Sprache dargestellt am Beispiel der Talkshow. In Wąsikiewicz-Firlej, Emilia \& Lankiewicz, Hadrian \& Szczepaniak-Kozak, Anna (eds.): Culture and creativity in discourse studies and foreign language pedagogy, 293-306. Piła: Wydawnictwo PWSZ.

Piosik, Michał. 2014b. Zu Besetzungsmöglichkeiten des Vorfeldes im gesprochenen Deutsch und der Erststelle im gesprochenen Polnisch. Ein korpusbasierter Vergleich der Sprache in Talkshows. In Język w poznaniu, 4. - Poznań: Wydaw. Rys, 199-214.

Poźlewicz, Agnieszka \& Duch-Adamczyk, Justyna \& Schatte, Christoph. 2013. Syntax des Deutschen im Abriss. Poznań: Wydawnictwo Rys.

Radojewska, Marta. 2008. Die Wortfolge in der Erzählung Unkenrufe von Günter Grass. Frankfurt a.M. et al.: Peter Lang.

Radojewska, Marta. 2013. Die Markierung des Konjunktivs vom Gotischen bis zum Neuhochdeutschen. Kwartalnik Neofilologiczny 1. 94-114.

Rapp, Irene. 1996. Zustand? Passiv? - Überlegungen zum sogenannten „Zustandspassiv“. In: Zeitschrift für Sprachwissenschaft. 15(2). 231-265.

Saloni, Zygmunt \& Świdziński, Marek. 2004. Składnia współczesnego języka polskiego. Warszawa: Wydawnictwo PWN.

Shipova, Irina. (Шипова И.А.) 2007. = Ob opyte pol'skih kolleg. Ûzef Darskij i ego model' stilističeskogo analiza (Об опыте польских коллег. Юзеф Дарский и его модель стилистического анализа.) In Naučnye trudy Moskovskogo pedagigičeskogo gosudarstvennogo universiteta. Filologičeskie nauki. Sbornik statej. (Научные труды Московского педагогического государственного университета. Филологические науки. Сборник статей.) - Moskva: Izd-vo Prometej MPGU, 278-285.

Steinke, Klaus. 2015. [Rec.] Deutsche Grammatik: ein völlig neuer Ansatz / Józef Paweł Darski. Informationsmittel (IFB): digitales Rezensionsorgan für Bibliothek und Wissenschaft <http://ifb.bsz-bw.de/bsz443023204rez-1.pdf $>$

Taborek, Janusz. 2001a. Versuch einer Klassifikation der Verweiswörter des Deutschen und Polnischen. Acta Neophilologica 3. 85-95.

Taborek, Janusz. 2001b. Lokale Verweiswörter des Deutschen und des Polnischen. Scripta Neophilologica Posnaniensia 4. 157-172.

Taborek, Janusz. 2002. Einige Probleme bei der Auffassung der Wortklasse Pronomina in den deutschen Grammatiken des letzten Jahrzehnts, In Rapp, Rheinhardt (ed.): Sprachwissenschaft auf dem Weg in das dritte Jahrtausend: Akten des 34. Linguistischen Kolloquiums in Germersheim 1999. Teil 1, Text, Bedeutung, Kommunikation, 339-345. Frankfurt a.M. et al.: Peter Lang.

Taborek, Janusz. 2004. Verweiswörter des Deutschen und des Polnischen. Frankfurt a.M. et al.: Lang. 
Tęcza, Zygmunt. 2008. Ein Grammatikmodell als Wegweiser: Anregungen aus dem linguistischen Analysemodell von Józef Darski für die Methodik einer kontrastiven deutsch-westslawischen Artikelbeschreibung. In: Mikołajczyk \& Kotin, 443-458.

Woźnicka, Marta. 2014a. Zum Wandel in den Personal- und Numerusexponenten im Konjugationsparadigma am Beispiel der starken Verben (Ablautreihe IV) vom Alt- bis zum Mittelhochdeutschen. Versuch einer Neuordnung. Jahrbuch für germanistische Sprachgeschichte 5. 194-206.

Woźnicka, Marta. 2014b. Zum Wandel in den Exponenten im Imperativparadigma vom Gotischen bis zum Neuhochdeutschen. Germanistische Werkstatt 6, 157-165.

Woźnicka, Marta. 2015. Das schwache Verb und seine Exponenten vom Mittel- bis zum Neuhochdeutschen. Kwartalnik Neofilologiczny 62(4). 703-713.

Zifonun, Gisela \& Hoffmann, Ludger \& Strecker, Bruno. 1997. Grammatik der deutschen Sprache. Berlin et al.: de Gruyter.

Żebrowska, Ewa. 2002. Morphologie der ehemaligen mitteldeutschen Kolonialmundart von Sętal und Umkreis. Olsztyn: Wydawnictwo UWM.

Żebrowska, Ewa. 2004. Die Äußerungsgliedfolge im Hochpreußischen. Olsztyn: Wydawnictwo UWM. 